\title{
Pengaruh Pernikahan Dini terhadap Kesehatan Mental dan Fisik: Sistematik Review
}

\author{
Azarine Pandita Widyadhara, Tasya Meilani Putri \\ Program Studi Kesehatan Masyarakat, Fakultas Ilmu Kesehatan, UPN Veteran Jakarta
}

\begin{abstract}
Abstrak
Latar Belakang: Dalam kehidupan rumah tangga pasti tidak luput dari permasalahan-permasalahan. Salah satu penyebab utama dalam permasalahan rumah tangga adalah belum dewasanya pasangan. Pernikahan dini terjadi disebabkan oleh beberapa faktor. Salah satu faktor yang sering ditemui di masyarakat yaitu karena faktor ekonomi. Faktor ini yang paling sering dijadikan alasan untuk menikahkan anak yang masih di bawah umur dengan seseorang yang dianggap mampu secara ekonomi.

Metode: Studi ini menggunakan desain sistematik review dengan mengikuti Panduan Pilihan untuk Ulasan Sytematic Review dan Meta Analyses (PRISMA) dan menggunakan flowchart berdasarkan daftar periksa PRISMA 2009, yaitu dengan menghilangkan artikel yang tidak relevan dengan menggunakan kriteria inklusi, penyaringan, kelayakan, dan pengunduhan akhir artikel yang relevan.

Hasil: Pernikahan yang dilakukan di usia muda sering terjadi dikarenakan perjodohan, kehamilan diluar nikah, dan faktor ekonomi. Berbagai macam faktor yang memicu hal tersebut terjadi karena adanya dorongan faktor ekonomi, kehamilan diluar pernikahan, mengalami putus sekolah, dan pengaruh pasangan untuk menikah muda. Pernikahan yang dilakukan di usia muda pun sering kali membuat pasangan mengalami kegagalan dalam meraih kesejahteraan psikologis.

Kesimpulan: Berdasarkan penelitian ini, dapat dilihat bahwa dalam pengaturan atas kehidupan anak yang bersifat normatif, seperti menikah diusia dini dapat menimbulkan atau menyebabkan berbagai dampak negatif bagi anak.
\end{abstract}

Kata Kunci: Dampak, Pernikahan muda, Faktor

\section{The Impact of Early Marriageon Mental and Physical Health: A System Review}

\begin{abstract}
Background: In the life of the household certainly is not free from problems. One of the main causes of problems in the household is couples who are not yet mature. Early marriage occurs due to several factors. One factor that is often encountered in the community is due to economic factors. This factor is most often used as an excuse to marry an underage child to someone who is considered economically capable.

Method: This study uses a systematic design review by following the Choice Guidelines for Sytematic Review and Meta Analyze Review (PRISMA) and using a flowchart based on the 2009 PRISMA checklist, namely by removing irrelevant articles using inclusion, filtering, eligibility, and final download criteria relevant article.

Results: Marriage conducted at a young age often occurs due to arranged marriages, extramarital pregnancy, and economic factors. Various types of factors that trigger this occur because of the crush of economic factors, the existence of pregnancy outside of marriage, having dropped out of school, and the influence of couples to marry young. Weddings conducted at a young age often make couples fail to achieve psychological well-being.

Conclusion: Based on this research, it can be seen that in regulating the lives of children who are normative, such as marrying at an early age can cause data or cause various negative impacts on children.
\end{abstract}

Keywords: Impact, young marriage, factors

Korespondensi: Azarine P. Widyadhara

Email: azarinepw@gmail.com 


\section{PENDAHULUAN}

Perkawinan anak yang ditetapkan oleh PBB sebagai perkawinan sebelum usia 18 tahun, dianggap sebagai pelanggaran hak asasi manusia dengan konsekuensi negatif bagi kesehatan anak perempuan ${ }^{1}$. Berdasarkan Undang-undang, perkawinan merupakan ikatan lahir batin yang dilakukan antara seseorang pria dengan seorang wanita sebagai suami istri yang bertujuan untuk membentuk keluarga (rumah tangga) yang bahagia dan kekal yang didasarkan atas Ketuhanan Yang Maha $\mathrm{Esa}^{2}$. Berdasarkan pada Undangundang Perkawinan, usia yang diizinkan untuk menikah adalah apabila pihak pria maupun wanita sudah mencapai umur 19 tahun $^{3}$. Walaupun demikian, berdasarkan ilmu kesehatan dan BKKBN menyarankan usia yang ideal untuk menikah adalah 2025 tahun bagi wanita dan 25-30 tahun bagi pria ${ }^{4}$. Hal ini dikarenakan pada usia tersebut sudah dianggap matang secara biologi maupun psikologis. Walaupun sudah mengetahui usia ideal untuk menikah, hal tersebut tidak luput dari masyarakat yang tetap menikah di bawah umur. Isu pernikahan dini ini sudah lama menjadi masalah nasional, internasional, maupun global $^{1}$.

Hasil penelitian Plan Indonesia bekerja sama dengan Pusat Studi Kependudukan dan Kebijakan (PSKK) UGM tahun 2011 tentang 'Praktik Pernikahan Dini di Indonesia' di delapan wilayah: Indramayu, Grobogan, Rembang, Tabanan, Dompu, Sikka, Lembata, dan Timur Tengah Selatan (TTS) menunjukkan bahwa rata-rata usia kawin di seluruh wilayah penelitian adalah 16 tahun. Dampak dari perkawinan anak berdasarkan temuan studi, antara lain terkait dengan kesehatan reproduksi. Hampir di semua wilayah penelitian, anak perempuan yang kawin pada usia muda berpotensi mengalami kehamilan berisiko tinggi. Dampak lain yang dirasakan oleh anak perempuan yang kawin di usia muda adalah adanya ancaman kesehatan mental. Anak perempuan sering kali mengalami stres ketika meninggalkan keluarganya dan bertanggung jawab atas keluarganya sendiri. Selain itu, perkawinan anak juga membawa dampak buruk bagi anak perempuan seperti rentan KDRT. Menurut temuan Plan, sebanyak $44 \%$ anak perempuan yang melakukan perkawinan dini, mengalami kekerasan dalam rumah tangga (KDRT) dengan tingkat frekuensi tinggi. Sisanya, $56 \%$ anak perempuan mengalami KDRT dalam frekuensi rendah. Selain tingginya angka KDRT, perkawinan anak berdampak juga pada kesehatan reproduksi anak perempuan. Anak perempuan berusia 10-14 tahun memiliki kemungkinan meninggal lima kali lebih besar, di masa kehamilan atau melahirkan, dibandingkan dengan perempuan berusia 20-25 tahun. Dari data di atas terlihat bahwa pernikahan anak memosisikan perempuan dalam kelompok rentan terkait dengan kesehatan reproduksi dan seksualitasnya 5 .

Di Indonesia pernikahan dini pada saat ini menurun dalam sepuluh tahun terakhir dan berada pada tingkat yang paling rendah yaitu $11,21 \%$ pada tahun 2018. Namun Indonesia masih merupakan negara dengan tingkat pernikahan dini yang masih cukup tinggi di kawasan Asia dan Pasifik $^{6}$. Wilayah Indonesia yang memiliki angka pernikahan dini tertinggi yaitu wilayah Sulawesi Barat dengan angka persentase di atas 19\% yang kemudian diikuti dengan wilayah Kalimantan Selatan. Sedangkan angka persentase yang paling rendah untuk kasus pernikahan dini berada di wilayah DKI Jakarta yaitu sekitar 4\%. Rendahnya kasus pernikahan dini di wilayah DKI Jakarta disebabkan oleh tingginya tingkat pendidikan dan perekonomian yang dimiliki oleh masyarakatnya ${ }^{7}$.

Dalam kehidupan rumah tangga pasti tidak luput dari permasalahanpermasalahan. Salah satu penyebab utama permasalahan dalam rumah tangga adalah pasangan-pasangan yang belum dewasa ${ }^{8}$. Pernikahan dini terjadi disebabkan oleh beberapa faktor. Salah satu faktor yang sering ditemui di masyarakat yaitu karena faktor ekonomi. Faktor ini yang paling sering dijadikan alasan untuk menikahkan anak yang masih di bawah umur dengan seseorang yang dianggap mampu secara ekonomi. Dengan kata lain, pernikahan dini terjadi agar dapat meringankan beban dan 
meningkatkan ekonomi keluarga. Selain itu, faktor pendidikan juga berperan besar dalam terjadinya kasus pernikahan dini, rendahnya tingkat pendidikan yang dimiliki oleh anak, orang tua, dan masyarakat menyebabkan kurangnya pengetahuan akan dampak yang ditimbulkan dari pernikahan dini ${ }^{9}$. Faktor lain yang mendukung terjadinya pernikahan dini antara lain, kecelakaan (merried by accident), melanggengkan hubungan antara dua keluarga, dan tradisi keluarga ataupun adat istiadat setempat ${ }^{10}$. Faktor kesehatan reproduksi ini sangat penting karena kesehatan reproduksi berpengaruh pada kualitas janin yang dihasilkan, dan juga mempengaruhi tingkat kesehatan ibu, karena majunya suatu negara dapat diimplikasikan dengan angka kematian $i b u^{11}$. Risiko usia menikah pada usia dini berhubungan dengan kejadian kanker leher rahim. Semakin dini seorang perempuan melakukan hubungan seksual semakin tinggi risiko terjadinya lesi prakanker pada leher rahim ${ }^{12}$.

$$
\text { Masalah pernikahan dini }
$$
merupakan isu yang penting bagi dunia dan negara. Pernikahan yang terjadi pada usia remaja pada umumnya akan menimbulkan berbagai masalah baik secara fisiologis, psikologis, maupun sosial ekonomi $^{13}$. Dampak pernikahan dini biasanya lebih tampak nyata pada wanita dibandingkan dengan pria. Oleh karena itu, penting dilakukan penelitian terhadap dampak yang timbul akibat terjadinya kasus pernikahan dini sehingga pembaca dapat memiliki pengetahuan lebih dan paham mengenai hal tersebut, serta dapat meminimalisir terjadinya kasus pernikahan dini dikemudian hari.

\section{METODE}

Studi ini menggunakan desain sistematik review dengan mengikuti Panduan Pilihan untuk Ulasan Sytematic Review dan Meta Analysis (PRISMA) dan menggunakan flowchart berdasarkan daftar periksa PRISMA 2009, yaitu dengan menghilangkan artikel yang tidak relevan dengan menggunakan kriteria inklusi, penyaringan, kelayakan, dan pengunduhan akhir artikel yang relevan. Artikel yang dicari didatabase secara online (Google Scholar, Garuda, ScienceDirect, Harvard, Oxford) untuk pengkajian dari hasil pernikahan dini dan pernikahan anak dibawah umur. Dengan menggunakan kata kunci "child marriage" OR "early marriage" AND "phychological" OR "mental" AND "impact" OR "affect" melalui jurnal Google Scholar, Garuda, ScienceDirect, Harvard dan Oxford. Kami menemukan 1049 Dokumen berdasarkan full text akses dokumen gratis, berdasarkan tahun publikasi (8 tahun), berdasarkan Bahasa inggris dan Bahasa Indonesia, Kemudian menyeleksi jurnal berdasarkan judul dan abstrak 25 Dokumen dan seleksi secara keseluruhan (full text) 3 dokumen untuk di analisis. Dan dipilih berdasarkan publikasi 8 tahun terakhir (2012-2020), Bahasa inggris, teks lengkap, dan memilih jurnal berdasarkan relevansi, penilaian kelayakan. Kriteria inklusi dokumen yang dianggap tepat (kelayakannya) untuk melakukan sistematik review adalah sebagai berikut: jurnal penelitian dalam bahasa inggris, diterbitkan 8 tahun terakhir (2012-2020). Kriteria inklusi untuk responden adalah anak perempuan yang telah menikah, dampak / hasil untuk kesehatan, studi desain dicampur. Kriteria eksklusi adalah sebagai berikut: menggunakan Bahasa Indonesia, diterbitkan kurang dari 2012, dampak non kesehatan. 


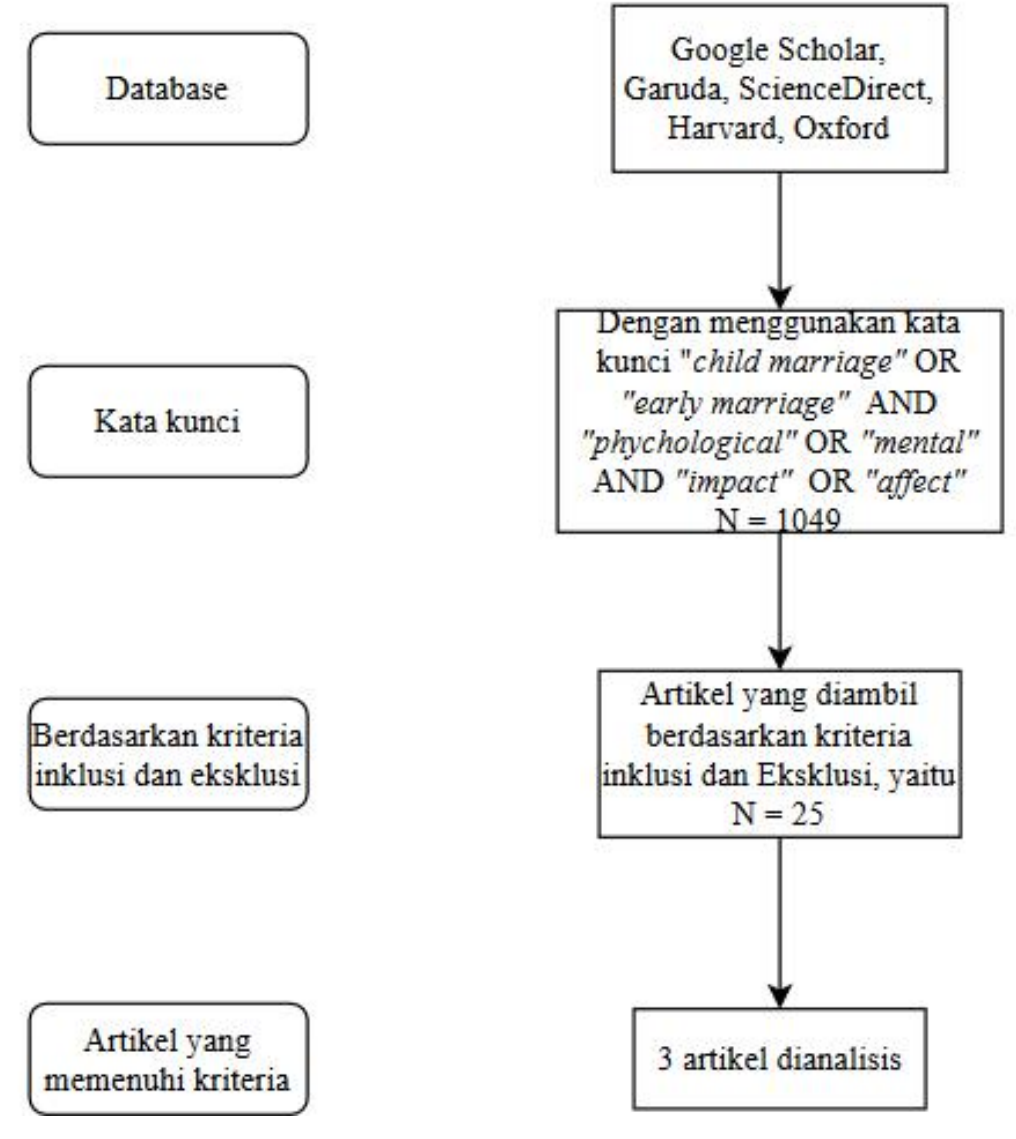

Gambar 1. Alur Pencarian Artikel

HASIL

Pernikahan yang dilakukan di usia muda sering terjadi dikarenakan perjodohan, kehamilan diluar nikah, dan faktor ekonomi. Berbagai macam faktor yang memicu hal tersebut terjadi karena adanya himpitan faktor ekonomi, adanya kehamilan diluar pernikahan, mengalami putus sekolah, dan pengaruh pasangan untuk menikah muda. Pernikahan yang dilakukan di usia muda pun sering kali membuat pasangan mengalami kegagalan dalam meraih kesejahteraan psikologis. Kegagalan dalam meraih kesejahteraan psikologis akan berdampak buruk terhadap pernikahan, yaitu perceraian dan terlantarnya anak. Pada remaja yang melakukan perkawinan rentan terhadap kegagalan dalam meraih kesejahteraan psikologis. Hal ini erat kaitannya dengan kematangan emosional dalam menyelesaikan konflik rumah tangga. Remaja yang tidak matang secara emosi berakibat pada timbulnya emosi negatif atau afek negatif. Kondisi ini berakibat pada situasi yang tidak menyenangkan dan menyusahkan selama menjalani rumah tangga14.

Dampak kesehatan yang mungkin ditimbulkan akibat pernikahan dini dari aspek fisik yaitu infeksi menular seksual, komplikasi saat bersalin, dan gangguan kesehatan pada anak. Sehingga dengan demikian semakin besar pula kemungkinan ditemukannya kanker leher rahim. Sedangkan aspek psikologis berupa beban pikiran. Di samping itu, dampak dari aspek sosial seperti celaan masyarakat, permaklumkan terhadap kasus menikah dini terlebih akibat perilaku seks pra nikah, hingga memicu tindakan kriminal ${ }^{15}$. 
Tabel 1. Ringkasan Deskriptif Karakteristik Penelitian

\begin{tabular}{|c|c|c|c|c|c|c|}
\hline No & $\begin{array}{c}\text { Penulis, } \\
\text { Tahun }\end{array}$ & Lokasi & $\begin{array}{c}\text { Jumlah } \\
\text { sampel }\end{array}$ & Studi & Kesimpulan & Statistik \\
\hline 1 & $\begin{array}{l}\text { John, N, } \\
\text { Edmeades, } \\
\text { J, Murithi, } \\
\text { L, } 2019\end{array}$ & $\begin{array}{l}\text { Nigeria } \\
\text { Ethiopia }\end{array}$ & 6.913 & Kualitatif & $\begin{array}{l}\text { Penelitian ini } \\
\text { menggarisbawahi } \\
\text { bahwa bahkan } \\
\text { dalam pengaturan } \\
\text { di mana } \\
\text { pernikahan anak } \\
\text { bersifat normatif, } \\
\text { menikah sangat } \\
\text { dini penuh dengan } \\
\text { hasil negatif. }\end{array}$ & $\begin{array}{llr}\text { Rata-rata, wanita dalam } \\
\text { sampel Niger berusia } 29 \\
\text { tahun, sedangkan } \text { wanita } \\
\text { dalam sampel Ethiopia } \\
\text { berusia } 30 \text { tahun }\end{array}$ \\
\hline 2 & $\begin{array}{l}\text { Setyawan, J, } \\
\text { Marita, I, } \\
2016\end{array}$ & $\begin{array}{l}\text { Jawa } \\
\text { Timur }\end{array}$ & 5 & Kualitatif & \begin{tabular}{lr}
\multicolumn{2}{l}{ Perkembangan } \\
identitas subjek \\
yang mengalami \\
pernikahan \\
masa di \\
menjadi muda, relatif \\
lambat.
\end{tabular} & $\begin{array}{l}\text { Provinsi Jawa Timur } \\
\text { berdasarkan data BPS } \\
\text { Surabaya Remaja Jawa Timur } \\
\text { tahun 2013, terdapat } \\
\text { setidaknya } 0,45 \% \text { dari seluruh } \\
\text { populasi anak di bawah umur } \\
16 \text { tahun yang memiliki status } \\
\text { kawin/cerai hidup/cerai mati. }\end{array}$ \\
\hline 3 & $\begin{array}{l}\text { Agustina, R, } \\
2018\end{array}$ & $\begin{array}{l}\text { Lombok } \\
\text { Timur }\end{array}$ & 123.324 & Kualitatif & $\begin{array}{l}\text { Hasil dari } \\
\text { penelitian ini dapat } \\
\text { digunakan sebagai } \\
\text { salah satu hasil } \\
\text { analisis komunitas } \\
\text { sebagai dasar } \\
\text { dalam } \\
\text { perencanaan } \\
\text { intervensi untuk } \\
\text { menanggulangi } \\
\text { permasalahan } \\
\text { pernikahan dini di } \\
\text { Kabupaten } \\
\text { Lombok Timur. }\end{array}$ & $\begin{array}{l}\text { Hasil Survei Demografi dan } \\
\text { Kesehatan Indonesia (SDKI) } \\
2012 \text { menunjukkan bahwa } \\
17 \% \text { perempuan pernah } \\
\text { kawin berusia 20-24 tahun } \\
\text { menikah sebelum usia } 18 \\
\text { tahun. Berdasarkan data } \\
\text { Susenas tahun 2008-2012, } \\
\text { diketahui bahwa rata-rata } \\
\text { persentase perempuan pernah } \\
\text { kawin usia 20-24 tahun. }\end{array}$ \\
\hline
\end{tabular}

\section{PEMBAHASAN}

Studi ini menemukan hubungan negatif yang signifikan antara pernikahan yang sangat awal (pernikahan pada 15 tahun atau lebih awal) dan kesejahteraan psikologis secara keseluruhan di Niger dan Ethiopia. Selain 'kontrol diri', semua subdomain kesejahteraan psikologis-depresi, kecemasan, kesejahteraan positif, vitalitas, dan kesehatan umum secara negatif terkait dengan pernikahan yang sangat dini. Temuan ini tetap kuat bahkan setelah disesuaikan dengan prevalensi pernikahan anak $^{16}$.

Kerusuhan, kekerasan dan kesejahteraan psikologis rata-rata di tingkat masyarakat, yang menunjukkan bahwa bahkan setelah memperhitungkan beberapa norma sosial yang ditangkap oleh variabel pernikahan anak dan variabel masyarakat lainnya, pernikahan dini sangat merusak kesejahteraan psikologis. Di antara faktorfaktor lain, IPV sangat terkait negatif dengan kesejahteraan psikologis di kedua negara $^{16}$. Dampak psikologis dari pelaksanaan pernikahan dini dapat menimbulkan terjadinya kecemasan, stres, depresi dan perceraian. Pada umumnya pasangan remaja kurang begitu memahami arti sebuah ikatan suci pernikahan, mereka melakukan pernikahan semata - mata hanya karena cinta dan dorongan dari orang tua si gadis agar anaknya lekas menikah supaya tidak dianggap sebagai perawan tua $^{17}$. 
\begin{tabular}{lrrr}
\multicolumn{2}{c}{ Beberapa } & mekanisme & mungkin \\
berperan dalam & hubungan antara \\
pernikahan dini dan kesejahteraan
\end{tabular} psikologis. Penelitian saat ini menunjukkan bahwa pernikahan dini sering membuat wanita berisiko tinggi mengalami IPV, komunikasi yang berkurang dengan suami atau pasangan, kurangnya pengetahuan tentang cara mengendalikan kesuburan, terbatasnya kemampuan untuk mengambil keputusan dan lebih sedikit akses ke sumber daya dibandingkan dengan wanita yang menikah saat dewasa ${ }^{16}$.

Sedangkan perkembangan identitas subjek yang mengalami pernikahan di masa muda, menjadi relatif lambat. Beberapa permasalahan yang muncul dalam rumah tangga subjek menunjukkan adanya kegagapan dalam menjalani peran menjadi seorang istri, suami, maupun orang tua. Respon seseorang saat mendapatkan permasalahan dalam rumah tangganya merepresentasikan orang tersebut belum siap untuk menjadi lebih dewasa ${ }^{14}$.

Selain itu, adanya campur tangan orang tua dalam menjalankan kehidupan rumah tangga seperti, finansialisasi, menampung tempat tinggal, dan merawat serta menjaga anak menunjukkan belum adanya komitmen yang benar-benar terjalin antara istri dan suaminya. Setelah seseorang menikah, terdapat perubahan hubungan sosial antara dia dengan beberapa orang di sekitarnya. Misalnya teman, beberapa orang mengaku memiliki keterbatasan jika ingin menjalin hubungan sosial dengan temannya. Beberapa orang merasa malu bahkan sengaja menutup diri dari teman-temannya. Sementara orang lain merasa canggung jika harus mengurus anak apabila bergabung dengan teman-temannya. Tidak hanya itu, rasa takut akan kecemburuan apabila pasangannya bermain dengan orang lain juga menunjukkan bahwa seseorang memilih untuk membatasi hubungan sosial mereka. Konsekuensinya, seseorang lebih cenderung membentuk atau membuat hubungan sosial yang baru dengan orangorang yang baru, misalnya tetangga dan teman yang baru ${ }^{14}$.

Perubahan emosi dialami oleh semua orang, hal tersebut muncul karena setiap orang mengalami permasalahan.
Belum matangnya usia emosi, menjadikan seseorang belum dapat memahami satu sama lain. Sehingga muncullah berbagai konflik yang memicu pertengkaran. Orang tersebut pun juga masih kolot dan tidak mau mengalah dalam menyelesaikan masalah rumah tangga. Hal tersebut diperkuat, misalnya seseorang mendapatkan permasalahan yang di sertai oleh kekerasan. Pengalaman tersebut membuat seseorang mengalami perasaan sakit hati dan meninggalkan kesan yang negatif terhadap permasalahan yang dihadapinya, sehingga memicu stres pada orang tersebut ${ }^{18}$.

Dilihat dari segi sosial, pernikahan dipandang sebagai sebuah prosesi yang dengannya dapat meningkatkan derajat seseorang. Dalam kehidupan bermasyarakat khususnya budaya Timur, seseorang yang menikah akan cenderung dinilai secara berbeda (lebih dihargai) ${ }^{19}$. Dampak sosial diantaranya faktor penyebab terjadinya pernikahan dini yaitu faktor pergaulan bebas, ekonomi, keinginan sendiri dan budaya $^{20}$.

\section{KESIMPULAN}

Berdasarkan penelitian ini, dapat dilihat bahwa dalam pengaturan atas kehidupan anak yang bersifat normatif, seperti menikah diusia dini dapat menimbulkan atau menyebabkan berbagai dampak negatif bagi anak. Pernikahan dengan usia yang dikatakan belum tepat pada waktunya akan menimbulkan banyak permasalahan, baik masalah fisik maupun masalah secara psikologi. Budaya yang berkembang di masyarakat juga ikut mempengaruhi pandangan mereka terhadap pengambilan keputusan mengenai pernikahan dini. Selain itu, adanya mitos yang melekat pada masyarakat, serta ketaatan terhadap orang tua menyebabkan anak (terlebih anak perempuan) mengikuti anjuran bahkan paksaan untuk segera menikah walaupun usia mereka masih belum matang, hal ini dikarenakan anak tidak memiliki kekuatan untuk menentukan kehidupannya.

\section{DAFTAR PUSTAKA}

1. Zaman M, Koski A. Child marriage in Canada: A systematic review. 
PLoS One. Maret 2020;15:e0229676.

2. Undang-undang (UU) tentang Perkawinan [Internet]. 1974. Tersedia pada: http://hukum.unsrat.ac.id/uu/uu_1_7 4.htm

3. Republik MK. Undang-undang (UU) tentang Perubahan atas Undangundang Nomor 1 Tahun 1974 tentang Perkawinan [Internet]. 16 Indonesia: LN.2019/NO.186, TLN NO.6401, JDIH.SETNEG.GO.ID : 4 HLM.; 2019 hal. 2-6. Tersedia pada: https://peraturan.bpk.go.id/Home/De tails/122740/uu-no-16-tahun-2019

4. Putri WD. BKKBN: Usia Pernikahan Ideal Berkisar 21-25 Tahun [Internet]. Republika Online. 2017 [dikutip 27 Februari 2020]. Tersedia pada: https://www.republika.co.id/berita/n asional/umum/17/03/06/omduca359 -bkkbn-usia-pernikahan-idealberkisar-2125-tahun

5. Kartikawati R. Dampak Perkawinan Anak di Indonesia. J Stud Pemuda. 2015;3(1):1-16.

6. UNICEF. Data Warehouse (Crosssector Indicators) [Internet]. UNICEF DATA. [dikutip 28 Februari 2020]. Tersedia pada: https://data.unicef.org/resources/dat a explorer/unicef_f/?ag=UNICEF\& $\mathrm{d} \overline{\mathrm{f}}=$ GLOBAL_DATAFLOW\&ver $=1$. $0 \& \mathrm{dq}=$.PT F 20 -

24_MRD_U $15+P T$ M 20 -

24_MRD_U18+PT_F_20-

24_MRD_U18..\&startPeriod $=2016$ \&endPeriod $=2020$

7. Harianja AJ. BKKBN: Angka Pernikahan Dini di Indonesia Masih Tinggi [Internet]. IDN Times. 2019 [dikutip 27 Februari 2020]. Tersedia pada:

https://www.idntimes.com/news/ind onesia/axel-harianja/bkkbn-angkapernikahan-dini-di-indonesia-masihtinggi/full

8. Siti M. Dampak Psikologis Pernikahan Dini dan Solusinya Dalam Perspektif Bimbingan Konseling Islam. 2010;
9. Syarifatunisa I. Faktor faktor penyebab pernikahan dini di kelurahan tunon kecamatan tegal selatan kota tegal [Internet]. 2017. 27-- 31 hal. Tersedia pada: https://lib.unnes.ac.id/29655/1/1201 412005.pdf

10. Mubasyaroh. Analisis Faktor Penyebab Pernikahan Dini dan Dampaknya Bagi Pelakunya. J Pemikir dan Penelit Sos Keagamaan [Internet]. 2016;7(2):385-411. Tersedia pada: https://www.google.com/url?sa=t\&r $\mathrm{ct}=\mathrm{j} \& \mathrm{q}=\& \mathrm{esrc}=\mathrm{s} \&$ source $=$ web\&cd $=$ $1 \&$ cad $=$ rja\&uact $=8 \&$ ved $=2$ ahUKE wjR2aTtuJPoAhUDfisKHVDsCsIQ FjAAegQIBhAB\&url=http $\% 3 A \% 2$ F\%2Fjournal.stainkudus.ac.id\%2Fin dex.php $\% 2$ FYudisia $\% 2$ Farticle $\% 2 \mathrm{~F}$ download\%2F2161\%2F1789\&usg= AOvVaw1jq3sf83CoyY14Nu9

11. Cipto Susilo AA. Pernikahan Dini Dalam Perspektif Kesehatan Reproduksi. Indones J Heal Sci. 2014;4(2):112-20.

12. Hanum Y, Tukiman. Dampak Pernikahan Dini Terhadap Kesehatan Alat Reproduksi Wanita. J Kel Sehat Sejah. 2015;13:36-43.

13. Lumbantoruan $M$, Sembiring $R$, Simanjuntak R. Faktor-Faktor Yang Berhubungan Dengan Di Kecamatan Tanjung Rejo Percut Sei Tuan Tahun 2017. J Reprod Heal [Internet]. 2017;2(2):64-77. Tersedia pada: e-journal.sarimutiara.ac.id/index.php/JRH/article/ view/327/328

14. Setyawan J, Marita R, Kharin I, Jannah M. Dampak Psikologis Pada Perkawinan Remaja Di Jawa Timur. J Penelit Psikol. 2016;7(2):15-39.

15. Agustini RT. Determinan Sosial dan Dampak Kesehatan Pernikahan Dini di Lombok Timur [Internet]. Vol. 34, UGM Public Health Symposium. Yogyakarta; 2018. Tersedia pada: https://jurnal.ugm.ac.id/bkm/article/ view/40472/23064

16. John NA, Edmeades J, Murithi L. Child marriage and psychological well-being in Niger and Ethiopia. 
BMC Public Health. 2019;19(1):1029.

17. Minarni M, Andayani A, Haryani S. Gambar Dampak Biologis dan Psikologis Remaja yang Menikah Dini di Desa Munding Kecamatan Bergas Kabupaten Semarang. J Keperawatan Anak. 2014;2:95-101.

18. Wilson CM, Oswald AJ. How does marriage affect physical and psychological health? A survey of the longitudinal evidence. Discuss Pap Ser. 2005;(1619):31.

19. Febrina N. Pernikahan Dini dan Dampaknya. 2018;

20. Afriani R, Mufdlilah. Analisis Dampak Pernikana Dini Pada Remaja Putri di Desa Sidoluhur Kecamatan Godean Yogyakarta. Rakernas Aipkema. 2016;235-43. 